\title{
Evidências de metamorfismo de alta pressão na faixa de dobramentos Pajeú - Paraíba, Província Borborema, nordeste do Brasil: petrografia e química mineral de rochas metamáficas
}

\author{
Cícera Neysi de Almeida', Ignez de Pinho Guimarães ${ }^{2}$, Hartmut Beurlen², \\ Werner Maximilian Topitsch ${ }^{3} \&$ Débora Maria de Melo Ferrer ${ }^{4}$
}

\begin{abstract}
Resumo Rochas metamáficas ocorrem como lentes concordantes em uma seqüência de migmatitos - ortognaisses de provável idade Paleoproterozóica. Neste trabalho são descritas e interpretadas a petrografia e química mineral de rochas metamáficas que ocorrem em Itabaiana - Itatuba na Faixa Pajeú-Paraíba, Província Borborema. A presença de granada enriquecida em $\mathrm{Mg}$ e Ca, anfibólio de composição Fe-edenita observadas nas coroas envolvendo granada e anfibólio tschermakítico nas simplectitas com plagioclásio circundando clinopiroxênio sugerem que as rochas estudadas foram metamorfisadas em condições de alta pressão e retro - metamorfisadas sucessivamente em condições de temperatura e pressão das facies granulito, anfibolito e xisto verde. Apesar de não ter sido preservado piroxênio onfacítico nas rochas estudadas, as texturas observadas e as relações de campo apontam para a ocorrência de um evento metamórfico em condições da facies eclogito. As rochas estudadas possivelmente marcam uma sutura paleoproterozóica no Domínio da Zona Tansversal da Província Borborema.
\end{abstract}

Palavras-chave: eclogito, metamáficas, zona de sutura, Província Borborema.

\begin{abstract}
Evidences of high pressure metamorphism in Pajeú-Paraiba fold belt, Borborema Province, Northeast Brazil: petrography and mineral chemistry in the metamafic rocks. Metamafic rocks occur as concordant lenses in a sequence of migmatites - orthogneisses of probably paleoproterozoic age. Petrographic and mineral chemistry investigations on metamafic rocks from Itatuba - Itabaiana, the Pajeú-Paraíba Belt of the Borborema Province, are reported. The presence of Mg-Ca-rich garnet, amphibole with Fe-edenite composition as coronas on the garnet grains and tschermakitic amphiboles in the symplectitic intergrowths with plagioclase around clinopyroxene suggest that the studied rocks were metamorphosed under high pressure conditions and that they were reequilibrated during a retrograde metamorphic path successively under temperature and pressure conditions of granulitic, amphibolitic and greenschist facies. In spite of the lack of omphacitic pyroxene in the studied rocks, the texture of the rocks and field relationships suggest the occurrence of a metamorphic event under eclogitic conditions. The studied rocks may mark a continental Paleoproterozoic suture zone in the Transversal Zone Domain of the Borborema Province.
\end{abstract}

Keywords: eclogite, metamafic rocks, suture zone, Borborema Province.

INTRODUÇÃO A Província Borborema (Almeida et al., 1977; Brito Neves, 1983) compreende um grande orógeno na região Nordeste do Brasil, formado durante o Ciclo Brasiliano (Pan-Africano; 0,70-0,57 Ga), cuja estruturação é constituída por quatro tipos de unidades maiores: núcleos arqueanos, blocos paleoproterozóicos; faixas de dobramentos neoproterozóicas (Tonianas); granitóides Brasilianos e extensas zonas de cisalhamento (Brito Neves et al., 1995a; Van Schmus et al., 1995; Vauchez et al. 1995).

Dois modelos procuram explicar os processos evolutivos responsáveis por essa configuração. De acordo com Santos (1995), Santos \& Medeiros (1997, 1999) e Brito Neves et al. (1995b; 2000), a Província Borborema é o resultado de acresção e colagem de terre- nos em diversos eventos tectônicos. Durante o primeiro evento, o Ciclo Transamazônico $(2,35-2,0 \mathrm{Ga})$ ocorreu a colagem dos núcleos arqueanos a blocos paleoproterozóicos préexistentes e extensiva produção crustal; um segundo evento, o Ciclo Cariris Velhos, ocorrido durante a transição Meso - Neoproterozóico Inferior (1,1$0,93 \mathrm{Ga}$ ), foi marcado pela amalgamação de diversos blocos decorrentes da fragmentação do supercontinente gerado no Transamazônico. Esse evento é indicado pela presença de xistos grauváquicos e metavulcânicas constituintes das sequências supracrustais neoproterozóicas da Faixa de Dobramentos Pajeú-Paraíba (Brito Neves \& Sato, 2001) e por metagranitóides com assinaturas geoquímicas de arco magmático (Santos, 1995; Brito Neves et al., 2000). Dentro desse contexto, em-

1 -UFRJ/IGEO, Departamento de Geologia, Rio de Janeiro (RJ), Brasil. E-mail: neysi@geologia.ufrj.br

2 -UFPE, Departamento de Geologia, Recife, (PE), Brasil. E-mails: ignez@ufpe.br; beurlen@ufpe.br

3 - UFPB, Departamento de Geociências, João Pessoa (PB), Brasil. E-mail: chefia@geociencias.ufpb.br

4 - Geólogo autônomo 
basamento e supracrustais compreenderiam terrenos distintos. Durante o Ciclo Brasiliano/Pan-Africano, convergência e colagem de blocos resultantes da fragmentação ocorrida no final do Ciclo Cariris Velhos, resultaria na formação de extensos cinturões colisionais na Província Borborema, integrando a porção centrooeste do Gondwana Ocidental.

Mariano et al. (1999), Neves et al. (2000) e Neves \& Mariano (2001) contestam o Ciclo Cariris Velhos como um evento orogenético completo e admitem que no final do Paleoproterozóico $(1,7 \mathrm{Ga})$ a Província Borborema já consistia de um único bloco, de características cratônicas. Segundo esses autores, as similaridades geoquímicas e isotópicas da maioria dos dioritos neoproterozóicos situados em diversos setores da Província Borborema, caracterizados por um componente mantélico enriquecido durante o Paleoproterozóico, não permitem a identificação de diferentes terrenos. Guimarães \& Brito Neves (2005) interpretaram as assinaturas geoquímicas dos granitóides do arco magmático relacionado ao Ciclo Cariris Velhos, como sendo similares às observadas em ambiente de rift continental.

Considerando que a Província Borborema teria sido submetida a pelo menos um evento orogenético, seria esperada a presença de remanescentes litológicos representativos do ambiente de subducção. Na Faixa Pajeú - Paraíba, um trend de rochas metamáficas foi identificado com direções gerais NE-SW a E-W, associadas a anomalias gravimétricas emparelhadas positivo-negativas (Rand et al., 1980, Costa et al., 1980; Beurlen, 1988). Dados de metamorfismo e litoquímica de duas ocorrências dessas metamáficas, situadas nos municípios de Floresta e Itatuba, indicam que essas rochas consistem de toleítos oceânicos de arco de ilhas, sendo interpretadas como os remanescentes de uma zona de sutura (Beurlen et al., 1992; Almeida et al., 1997). Alguns autores, baseados em correlações estruturais, têm recorrido a essas ocorrências para marcar os registros de subducção do Ciclo Cariris Velhos (Medeiros \& Torres, 1999; Santos \& Medeiros, 1999) ou Brasiliano (Bittar, 1998).

Neste trabalho são apresentadas e discutidas as texturas e a química mineral de rochas metamáficas e as condições do metamorfismo das ocorrências de Queimadas, Itatuba, Salgado de São Félix e Itabaiana, que representam as ocorrências extremo orientais do trend descrito acima.

GEOLOGIA REGIONAL A Faixa Pajeú-Paraíba (Brito Neves, 1983) está localizada no Domínio da Zona Transversal da Província Borborema, delimitado, a norte e a sul, respectivamente, por lineamentos de direção E-W, denominadas zonas de cisalhamento Patos e Pernambuco (Fig. 1A).

Dados petrológicos, estruturais e geocronológicos $\mathrm{Rb}-\mathrm{Sr}$, U-Pb e $\mathrm{Sm}-\mathrm{Nd}$ permitem dividir a Faixa Pajeú-Paraíba (FPP) em dois segmentos separados por extensas zonas de cisalhamento: a) uma fatia setentrional que estende-se de leste a oeste ao longo da FPP, formada pelas seqüências supracrustais de idade meso a neoproterozóicas, consideradas como constituintes de um terreno distinto, o Terreno Alto Pajeú (Santos, 1995; Oliveira e Santos, 1996; Santos e Medeiros, 1997; 1999); b) o segundo segmento, mais a sul, abrange as porções central e leste da FPP e é constituído por blocos paleoproterozóicos com núcleos e evidências de protólitos arqueanos, (Brito Neves et al 2001a, 2001b) que compreende o embasamento da FPP, definido como

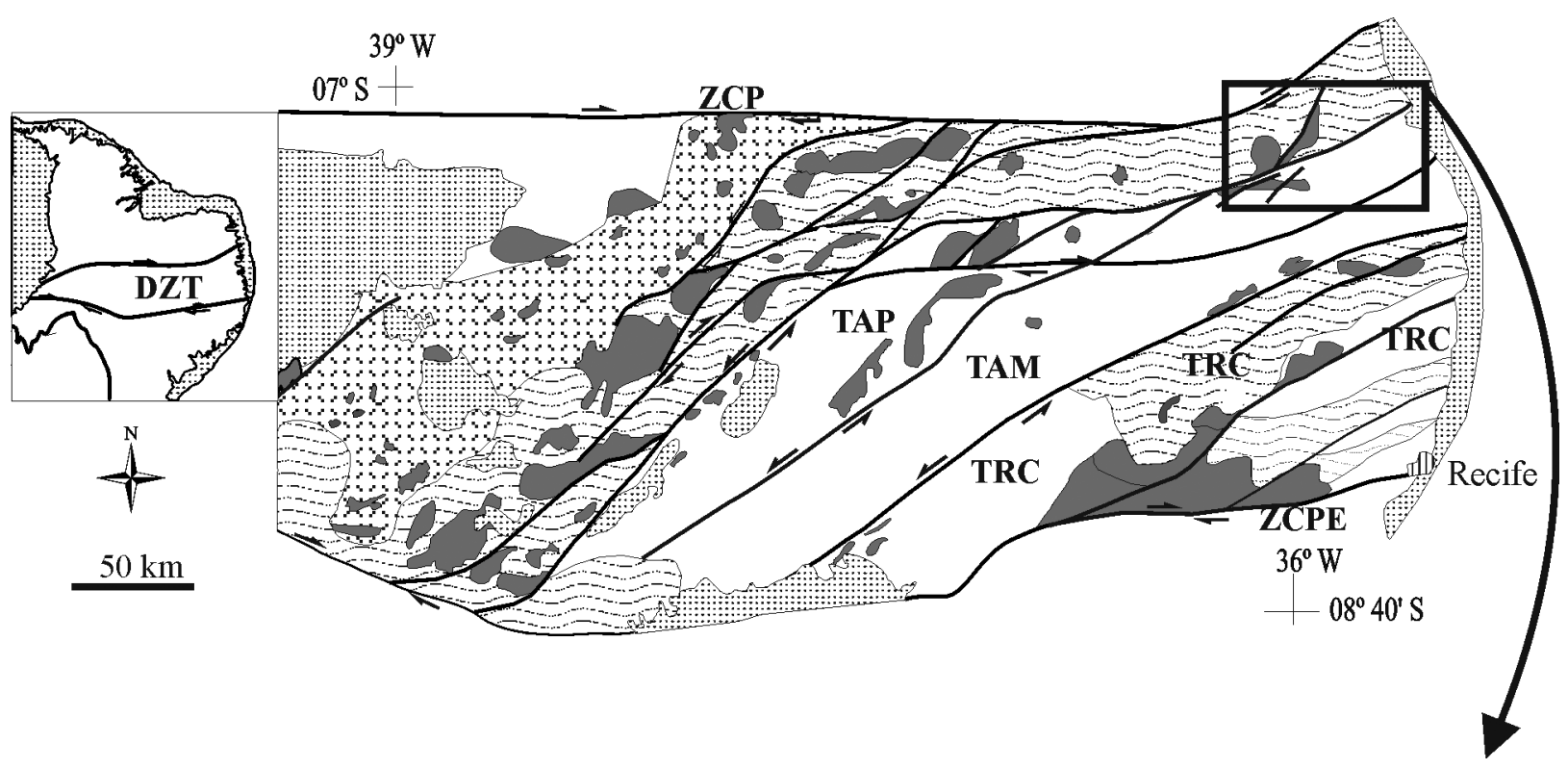

Figura $1 A$ - Esquema geológico da Zona Transversal (Província Borborema), mostrando o trend de rochas metamáficas. DZT (Domínio da Zona Transversal); TPB (Terreno Piancó-Alto Brígida); TAP (Terreno Alto Pajeú); TAM (Terreno Alto Moxotó); TRC (Terreno Rio Capibaribe). Fonte: modificado de Medeiros \& Santos (1997). 


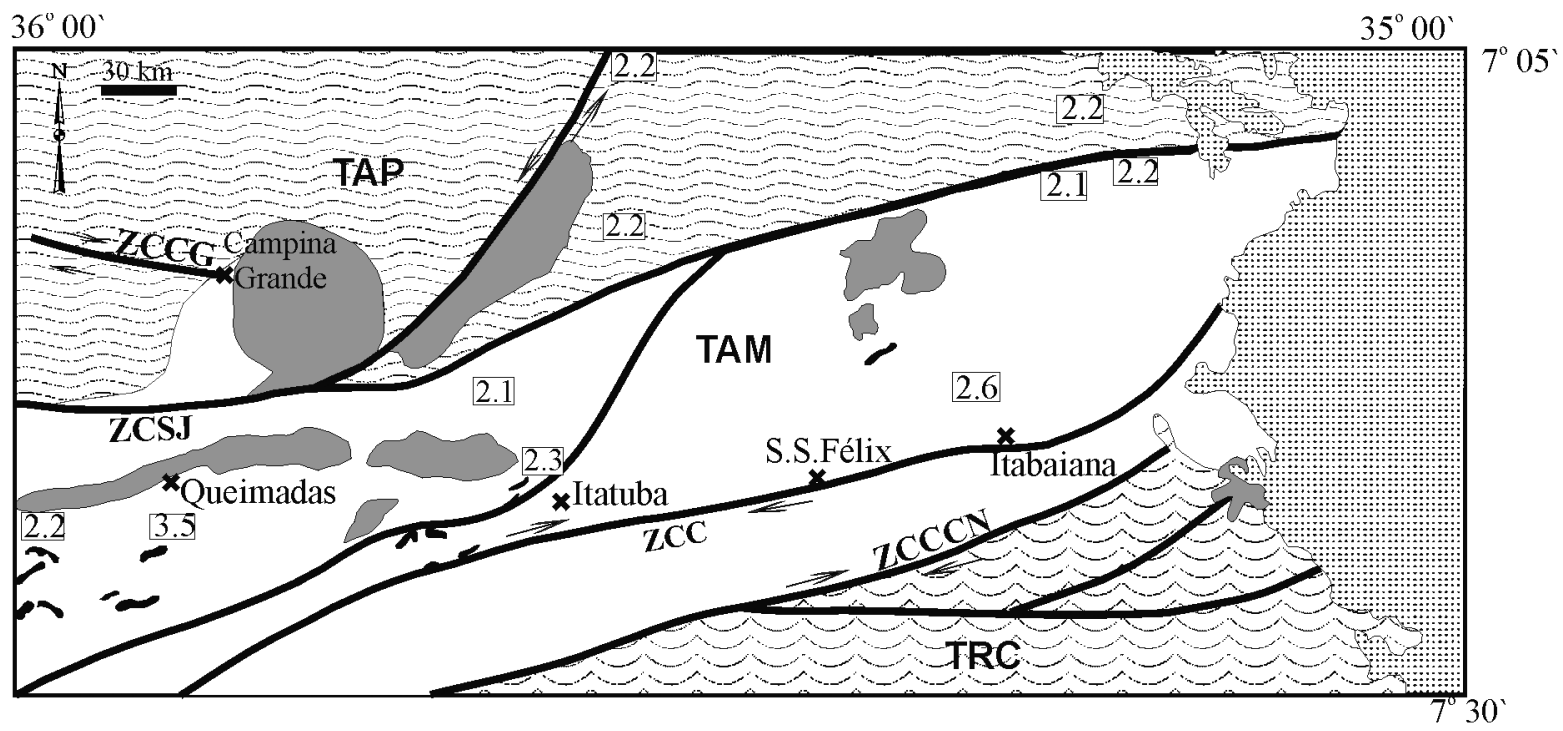

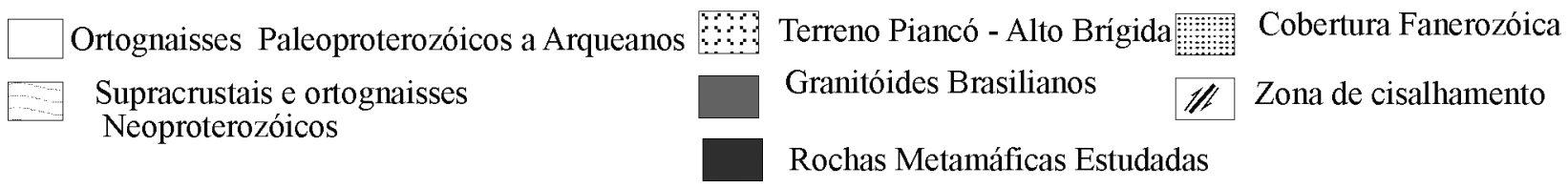

Figura 1B- No detathe, esboço geológico da porção extremo leste da Faixa de Dobramentos Pajeú-Paraíba, mostrando a localização das rochas metamáficas estudadas.

Terreno Alto Moxotó (Santos, 1995; Oliveira e Santos, 1996; Santos e Medeiros, 1997; 1999).

Rochas metamáficas distribuem-se ao longo de aproximadamente $180 \mathrm{~km}$ de extensão no Terreno Alto Moxotó, desde seu extremo oeste, no município de Floresta, verificando-se a ocorrência das mesmas nos municípios de Custódia, Camalaú, Queimadas, Itatuba, Salgado de São Félix, até próximo à costa no município de Itabaiana (Fig. 1B). As unidades litológicas aflorantes nessa região incluem rochas metamorfizadas a alto grau, cujos contatos são definidos por zonas de cisalhamento; são elas: ortognaisses granodioríticos porfiríticos, ortognaisses bandados laminados e ortognaisses peraluminosos, todos migmatizados durante o evento Brasiliano (Brito Neves et al., 2001b).

GEOLOGIA LOCAL E PETROGRAFIA Relictos de rochas metamáficas de alto grau na região de Queimadas - Itatuba - São Felix ocorrem como lentes de extensão geralmente centimétrica a métrica, intercaladas nos ortognaisses bandados laminados. Nessa associação também se observa metaultramáficas, mármores, calciossilicáticas e minério de Fe-Ti.

Os ortognaisses exibem coloração de branca a cinza escura, granulometria média e a associação plagioclásio (bitownita) + microclina + hornblenda + biotita + quartzo indica que o metamorfismo se deu sob condições de facies anfibolito. Dissolução e reprecipitação de aglomerados microcristalinos de quartzo/feldspato e presença de mirmequita confirmam condições de alta temperatura, segundo os critérios definidos por Simpson (1985) e Vernon (1991). Relictos de clinopiro- xênio e ortopiroxênio envoltos por anfibólio e minerais opacos sugerem uma fase mais antiga na facies granulito. Nessas rochas, observa-se um bandamento composicional $\left(\mathrm{S}_{\mathrm{n}}\right)$ com direção variando de NE-SW a E-W e mergulho suave para sul, marcado pela intercalação de faixas de composição granítica e faixas granodioríticas a monzodioríticas. Dobramento de $\mathrm{S}_{\mathrm{n}}$ gera dobras isoclinais e foliação plano-axial $\left(\mathrm{S}_{\mathrm{n}+1}\right)$, padrão este, também observado nas lentes de metamáficas; cisalhamento de caráter rúptil/dúctil, desenvolvendo foliação do tipo C-S, constitui o evento final de deformação.

Rochas metamáficas na área de Salgado de São Felix - Itatuba - Queimadas As rochas metamáficas relacionadas às ocorrências de Salgado de São Félix, Itatuba e Queimadas apresentam quatro facies petrográficas - texturais: granada-piroxenitos, anfibolitos bandados, anfibolitos maciços e piroxenitos, que passam gradativamente uma para outra.

Os granada-piroxenitos exibem coloração verde escura a levemente castanha (de acordo com a quantidade modal de granada), granulação média a fina, podendo exibir estrutura maciça ou bandada incipiente. Ocorrem como nódulos ou pods dentro dos anfibolitos e ortognaisses (Fig. 2).

Sua mineralogia é constituída por granada, clinopiroxênio, ortopiroxênio, anfibólio, opacos e quartzo. Como minerais secundários, observa-se a presença de plagioclásio, calcita e clorita. A granada ocorre freqüentemente, como cristais subeuédricos a anédricos, envoltos por coroas simplectíticas de anfibólio e plagioclásio (Fig. 3a). Granada envolta por clinopiroxênio é comumente 

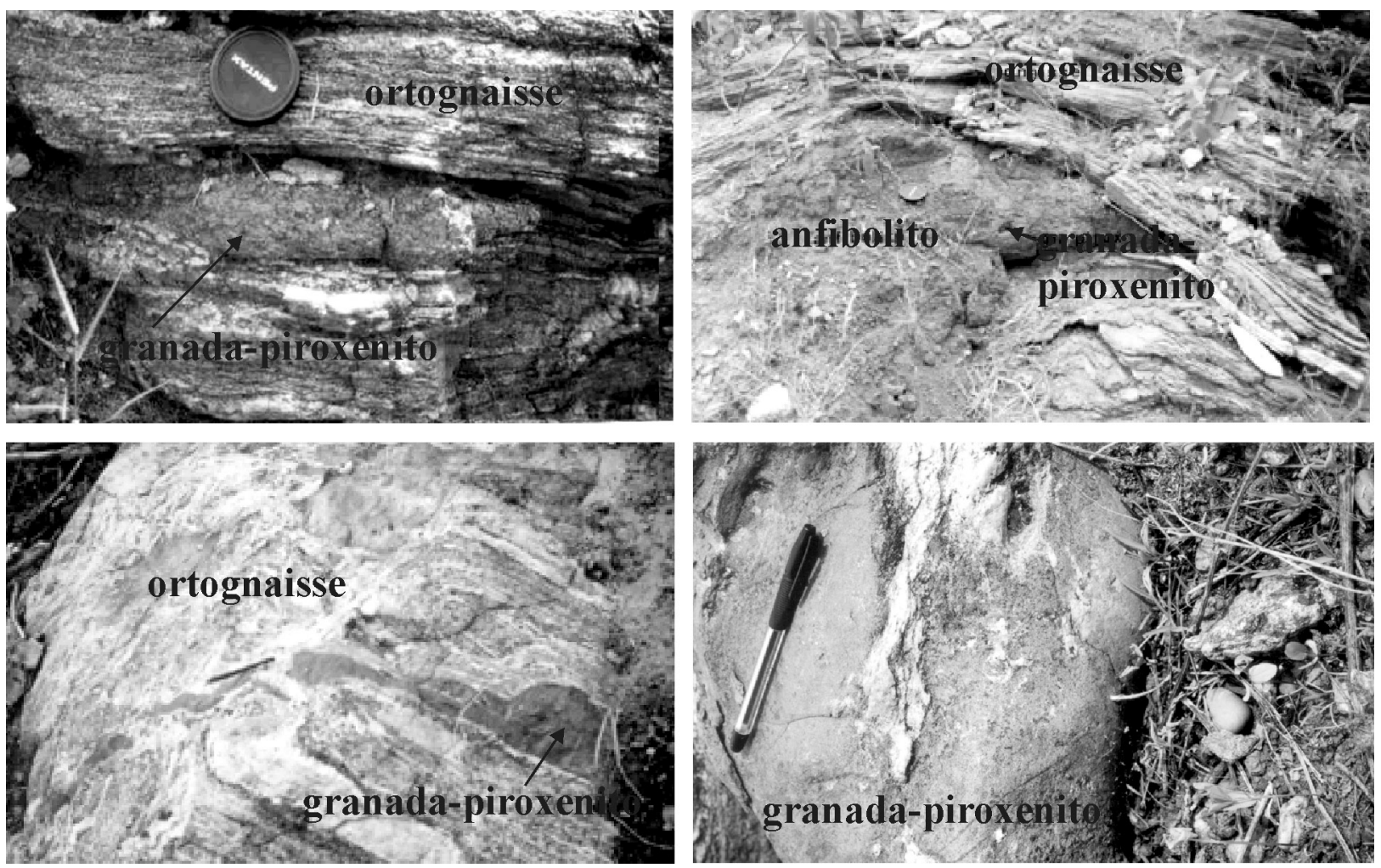

Figura 2 - Aspectos de campo dos granada-piroxenitos: a) lentes subparalelas encaixadas em ortognaisses; b) pods em anfibolitos encaixados nos ortognaisses; c) como lentes deformadas; d) como blocos soltos encaixadas nos ortognaisses.

observada mostrando bordos substituídos por anfibólio, preservando ainda contatos retos, sugerindo que granada e clinopiroxênio constituem os prováveis remanescentes de uma fase metamórfica mais antiga (Fig. 3b). Eventualmente, a granada ocorre em equilíbrio com quartzo e clinopiroxênio. Nas diversas associações, a granada apresenta, comumente, os bordos substituídos por clorita, indícios de retrometamorfismo para a facies xisto verde.

O clinopiroxênio pode ocorrer formando textura de equilíbrio com granada e ortopiroxenio segundo as seguintes paragêneses, clinopiroxênio + ortopiroxênio + plagioclásio + anfibólio e clinopiroxênio + granada constituindo assembléias estáveis na facies granulito (Fig. 3c, 3d). Esta última associação é comumente envolta por coroas de ortopiroxênio que, por sua vez, desestabiliza-se para formar anfibólio e plagioclásio. Além de apresentar as feições acima descritas, o clinopiroxênio ocorre sob a forma de cristais reliquiares, formando textura de equilíbrio com a granada, inclusos em uma matriz constituída de plagioclásio ou constituindo texturas coroníticas, nas quais o mesmo ocorre envolto por simplectitas de ortopiroxênio + plagioclásio (Fig. $3 \mathrm{f}$ e $3 \mathrm{e}$, respectivamente). As simplectitas evoluem para aglomerados neocristalizados de anfibólio + plagioclásio. Verifica-se com a progressão das reações metamórficas o desaparecimento gradativo da granada que é consumida na formação de anfibólio e plagioclásio, restando clinopiroxênio em condições metaestáveis já na presença de anfibólio e plagioclásio em equilíbrio. Texturas coroníticas constituídas por simplectitas de anfibólio+plagioclásio e ortopiroxênio + plagioclásio, envolvendo granada e clinopiroxênio, respectivamente, evidenciam uma origem por retrometamorfismo a partir de rochas da facies eclogito, configurando a desestabilização, por descompressão, de clinopiroxênio onfacítico e granada tipo piropo (Mysen, 1972; Messiga et al., 1991).

O plagioclásio pode ser encontrado: incluso na granada, provavelmente, como relictos da fase ígnea; em equilíbrio com a granada e clinopiroxênio; ou como mineral tardio, constituindo a matriz. Neste caso, o plagioclásio apresenta textura poiquiloblástica, englobando as associações granada+clinopiroxênio (Fig. $4 \mathrm{a}, \mathrm{b}$ ), e os diversos intercrescimentos que envolvem as simplectitas indicando ter-se formado após a fase de metamorfismo de alta pressão.

As relações texturais observadas indicam paragênese transicional das condições de facies granulito de alta $\mathrm{P}$ para facies granulito de baixa $\mathrm{P}$, evoluindo para paragênese de condições de facies anfibolito, a partir de associações pretéritas que teriam sido geradas em condições de facies eclogito. Esta evolução é marcada pelo desaparecimento gradual de granada e clinopiroxênio que se desestabilizam para formar anfibólio+plagioclásio. Diante dessas evidências, os granada-piroxenitos podem ser caracterizados como retroeclogitos, sendo a partir desse ponto, assim referidos.

A primeira descrição de eclogito na Província Borborema foi feita por Zenaide de Melo em rochas me- 

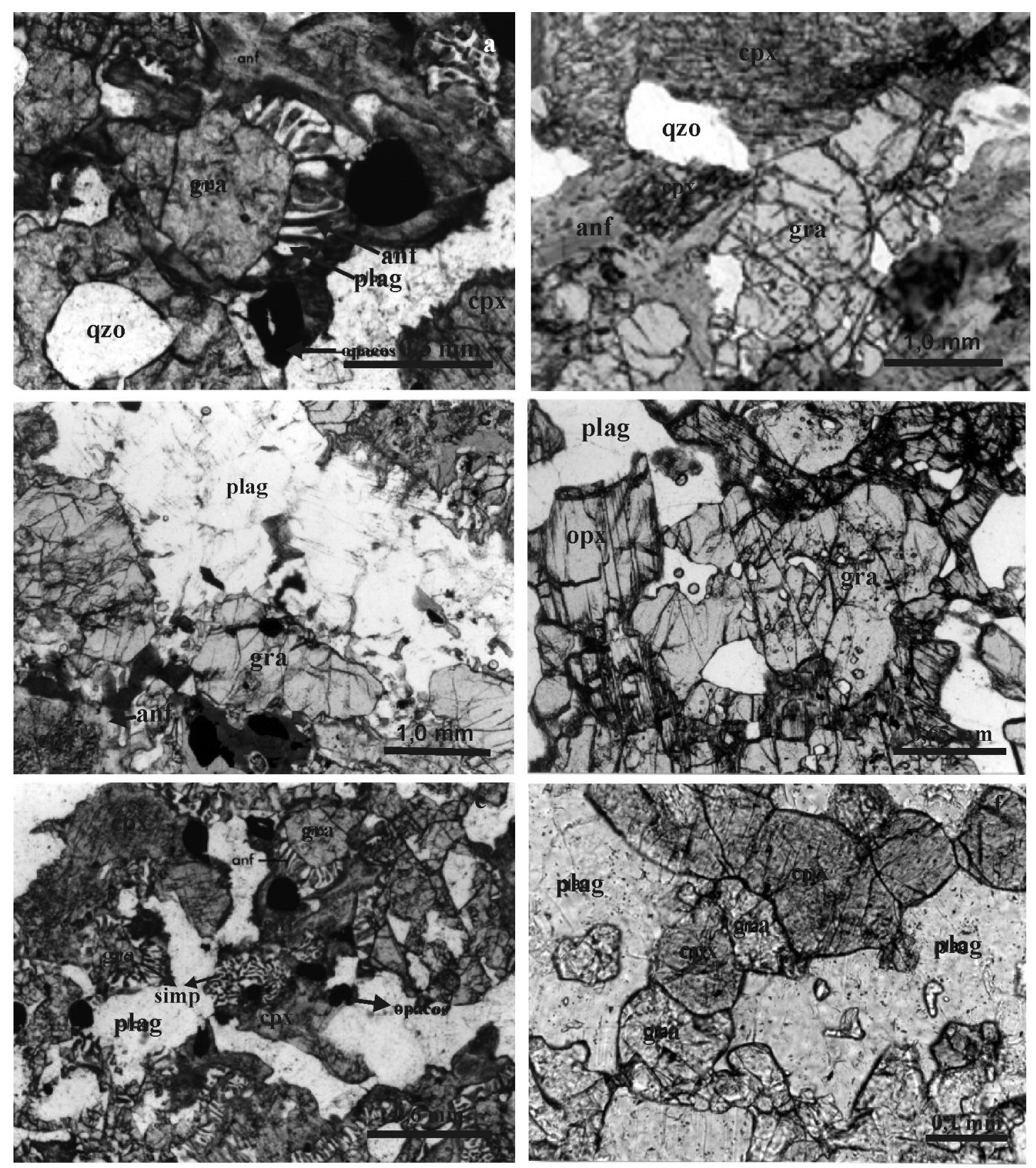

Figura 3 - a) granadas envoltas por coroas simplectíticas de anfibólio + plagioclásio; b) granadas em contatos retos com clinoíroxênios com bordos de anfibólio; c) clinopiroxênio + granada envoltos por coroas de palgioclásio e anfibólio; d) granadas envoltas por coroas de ortopiroxênio; e) clinopiroxênio envoltos por simplectitas de ortopiroxênio + plagioclásio e granadas envoltas por simplectitas de anfibólio + plagioclásio; f) granadas e clinopiroxênio em textura de equilíbrio inclusos em matriz de plagioclásio.

tamáficas da região de Queimadas (Costa et al., 1980). Infelizmente, o afloramento citado neste trabalho não foi encontrado, possivelmente devido à destruição do mesmo durante expansão das rodovias na região.

Os anfibolitos bandados têm como minerais essenciais hornblenda, plagioclásio, clinopiroxênio, e quartzo. Seu bandamento composicional definido por níveis submilimétricos constituídos essencialmente por anfibólio/clinopiroxênio intercalados por níveis ricos em plagioclásio (Fig 4c). A hornblenda apresenta coloração verde-amarronzada (indício de cristalização em alta tem- peratura) e, localmente, constitui aglomerados monominerálicos. Altera para tremolita, epidoto, calcita e clorita, atingindo condições da facies xisto verde (Fig. 4d).

Nos anfibolitos maciços ocorrem nódulos preservados de piroxenitos constituídos por clinopiroxênio e anfibólio, com fases acessórias abrangendo plagioclásio, ortopiroxênio, titanita e minerais opacos. Exibem textura granoblástica definida por clinopiroxênio, anfibólio e ortopiroxênio cristalizados em equilíbrio. O plagioclásio ocorre como cristais milimétricos nos interstícios deixados pelos minerais essenciais. A titanita 

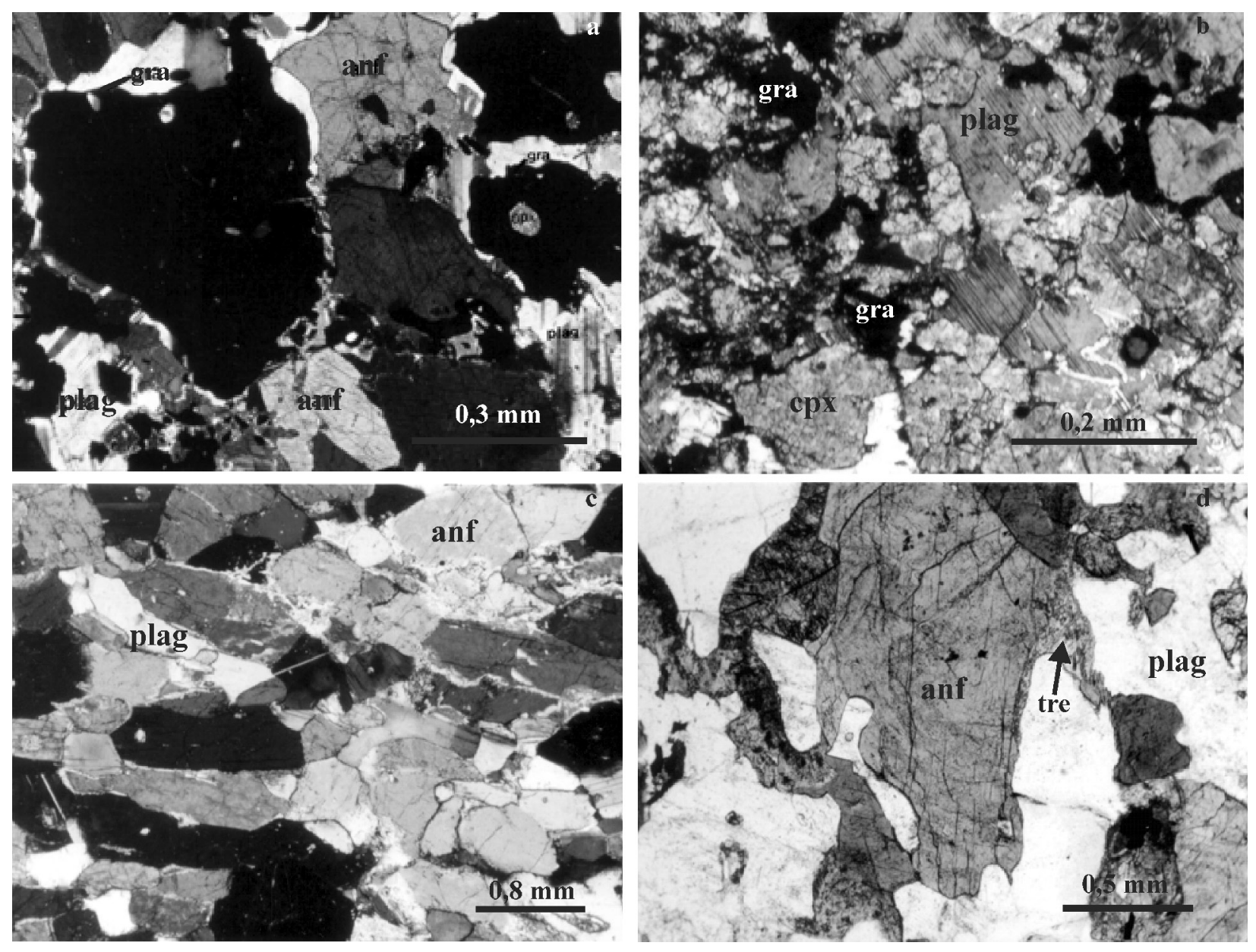

Figura 4 - a) granadas reliquiares inclusas em matriz de palgioclásio; b) relictos de clinopiroxênio inclusos em matriz de palgioclásio; c) anfibólio e plagioclásio em associação de equilíbrio; d) hornblenda com bordas de tremolita.

formada às expensas dos minerais opacos, forma aglomerados. Clorita, calcita e talco ocorrem como produtos de alteração de clinopiroxênio e anfibólio, indicando retrogressão para condições da facies xisto verde.

Lentes centimétricas de rochas metaultramáficas ocorrem intercaladas nos ortognaisses. Um primeiro tipo é constituído por agregados de clinopiroxênio ricos em exsoluções de ortopiroxênio e com inclusões de espinélio verde (hercinita). Os seus bordos apresentam franjas de alteração para carbonato que, por sua vez, evolui até formar cristais subeuédricos, preeenchendo os interstícios entre grãos de clinopiroxênio. O plagioclásio constitui uma fase mineral tardia, apresentandose como cristais em continuidade ótica englobando os clinopiroxênios; anfibólio mostra contatos retos com o plagioclásio e, mais raramente, apresenta-se como coroas em torno do clinopiroxênio, sugerindo que a rocha pode ter sofrido retrometamorfismo, atingindo condições metamórfica das facies anfibolito e xisto verde. O segundo tipo compreende rochas de textura granoblástica, constituídas predominantemente por grãos de olivina envoltos por coroas de anfibólio. Alteram para clorita e opacos. Essas associações são compatíveis com protólitos gabróicos ou peridotíticos.
Metamáficas de Itabaiana As relações petrográficas/texturais indicam que as rochas metamáficas de Itabaiana registraram duas fases metamórficas, nas facies granulito e anfibolito, não se observando indícios de metamorfismo na facies eclogito. A associação da facies granulito na ocorrência de Itabaiana é constituída por porfiroblastos subeuédricos a anédricos de granada $(0,4-$ $1,5 \mathrm{~mm}$ ), envoltos por coroas de pseudomorfos clinopiroxênio/ anfibólio+plagioclásio. Essas coroas evoluem para um mosaico granoblástico fino de clinopiroxênio/ anfibólio e plagioclásio, constituindo a matriz da rocha que substitui os cristais de granada que apresentam elevado estado de corrosão. Localmente, plagioclásio ocorre como aglomerados de cristais mais desenvolvidos (com cerca de $0,5 \mathrm{~mm}$ ), os quais mantêm contatos lobulados a suturados entre si, incluindo, total ou parcialmente, grãos de clinopiroxênio, sugerindo recristalização de uma fase mais tardia de plagioclásio. A transição para a facies anfibolito é caracterizada pelo desenvolvimento de assembléias granoblásticas mais grossas $(0,2-0,5 \mathrm{~mm})$ de anfibólio+plagioclásio e o total desaparecimento de clinopiroxênio. Pequenos fragmentos reliquiares de granada, totalmente inclusos em plagioclásio e ortopiroxênio e eventualmente nas bordas de anfibólio, 
constituem fases metaestáveis, o que, juntamente com a ausência do clinopiroxênio, demonstra o consumo de granada, clinopiroxênio e ortopiroxênio para a formação da assembléia estável na facies anfibolito.

QUÍMICA MINERAL As análises de química mineral foram realizadas na Universidade de Brasília (Brasil), utilizando uma microssonda eletrônica modelo CAMECA SX50 e na Universidade de São Paulo (Brasil), utilizando uma microssonda eletrônica modelo JEOL SUPERPROBE e abrangeram os retroeclogitos e anfibolitos. Procedeu-se análises pontuais de bordo e núcleo em granada, piroxênios, anfibólio, plagioclásio e olivina e perfis analíticos em granada, ortopiroxênio e clinopiroxênio.

Granada Os grãos de granada analisados nas rochas metamáficas das regiões de Itatuba, Queimadas e Salgado de São Félix, envoltos por coroas simplectíticas e aqueles em equilíbrio com clinopiroxênio e plagioclásio ( \pm ortopiroxênio) são geralmente ricos em almandina $(56-72 \% \mathrm{~mol})$, com teores razoáveis de grossulária $(18.5-23.5 \% \mathrm{~mol})$ e piropo $(7-20 \% \mathrm{~mol})$ - Fig. 5. São levemente zonados, mostrando decréscimo em $\mathrm{Ca}$ e $\mathrm{Mg}$ e aumento em Fe e Mn do núcleo para a borda (Fig. 6a). Comportamento distinto, com leve diminuição de Fe do núcleo para a borda, também pode ser observado (Fig. 6b). Eventualmente, grãos mais preservados de granada mostram comportamento contrário, com núcleos mais ricos em $\mathrm{Mg}$ e $\mathrm{Ca}$.

Apesar das relações texturais ainda serem típicas da facies granulito, os teores extremamente elevados em almandina são compatíveis com metamorfismo sob condições de facies anfibolito. A transição da facies granulito para a facies anfibolito é evidenciada principalmente pelo decréscimo de $\mathrm{Ca}$ e $\mathrm{Mg}$ nas granadas de eclogitos anfibolitizados, devido ao consumo desses elementos para a formação das simplectitas e a transferência de Fe para as granadas (Cox \& Indares, 1999; Wain et al., 2001; Yang, 2004).

Teores anômalos de grossulária $(40,9$ - 68,5) foram registrados nas granadas reliquiares em equilíbrio com clinopiroxênio inclusos no plagioclásio secundário constituinte da matriz (Fig. 4). Essas granadas poderiam representar fases reliquiares da facies eclogito. Entretanto, seu baixo conteúdo em piropo $(0,3$ - 1,0) e os teores anomalamente baixos em $\mathrm{Na}$ dos clinopiroxênios associados, sugerem que o enriquecimento em $\mathrm{Ca}$ foi controlado por difusão dos plagioclásios hospedeiros. Granada com composição típica da facies eclogito (pir $=37 \%$; gross $=59,5 \%$, alm $=3,5 \%$ ) foram registradas em apenas uma amostra (555B). Os teores baixos de $\mathrm{Na}$ nos clinopiroxênios associados sugerem que o $\mathrm{Na}$ foi quase que totalmente consumido durante os processos de anfibolitização na formação da pargasita.

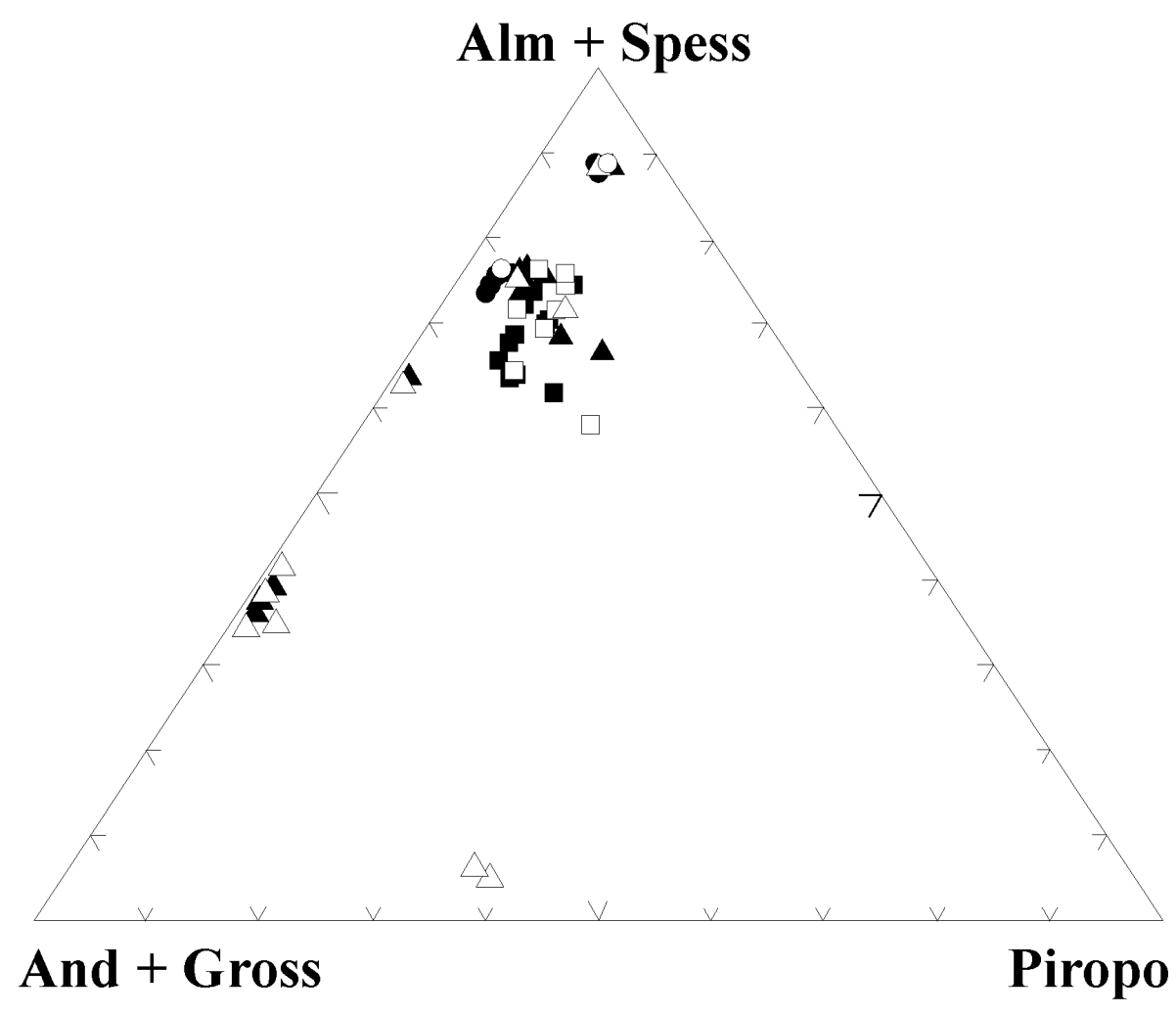

Figura 5 - Diagrama Gro+And x Alm + Espes x Pi (Deer et al., 1962) mostrando a classificação da granada das rochas estudadas. Símbolos: Itabaiana - . (análises de núcleo); $\square$ (análises de borda); Queimadas (análises de núcleo); O (analise de borda); Itatuba e Salgado de São Félix - $\Delta$ (análise de núcleo); $\triangle$ (análise de borda). 

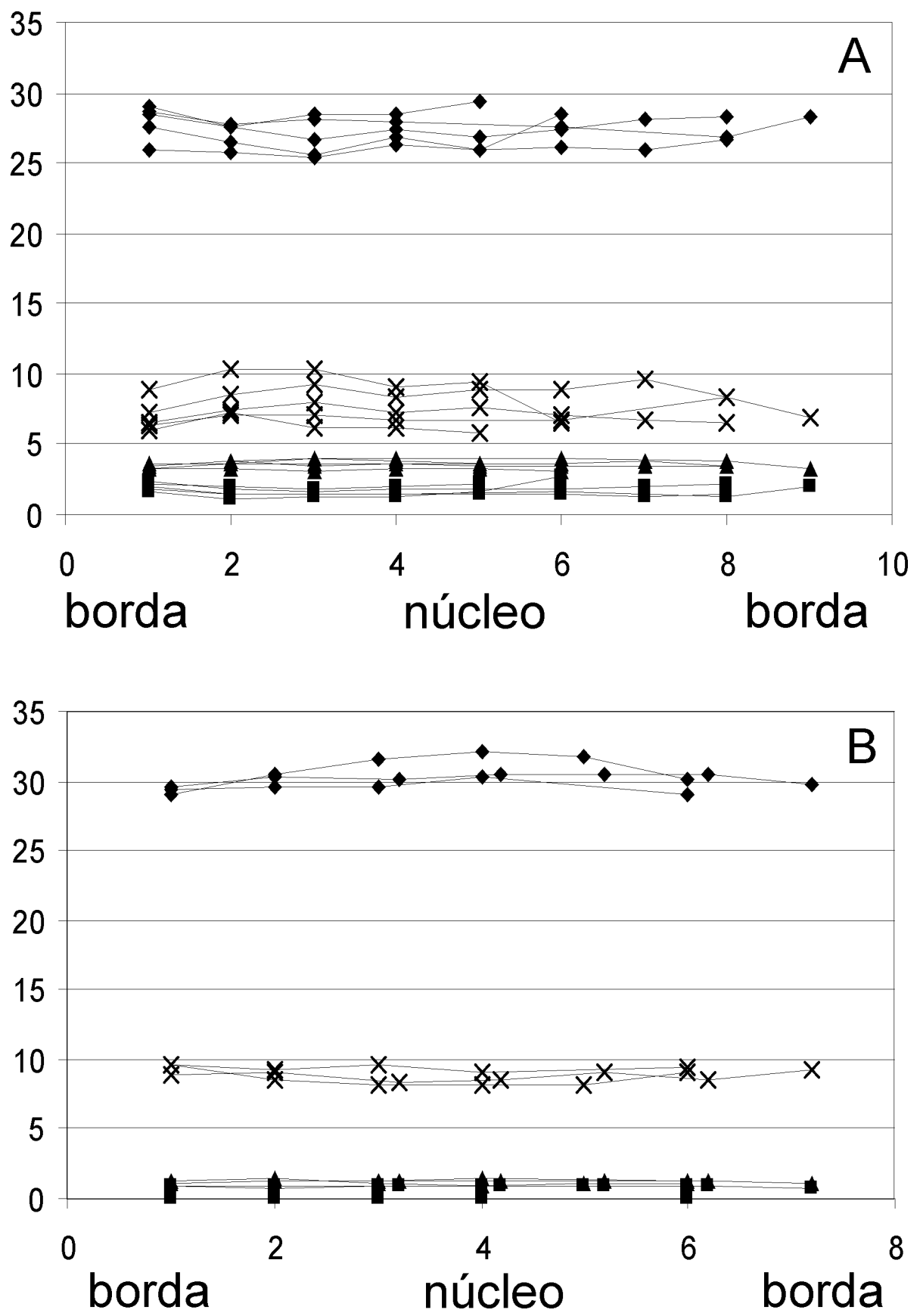

Figura 6 - Perfis analiticos para grãos de granada que ocorrem como porfiroblastos envoltos por clinopiroxênio com bordas de anfibólio. A) amostra proveniente de Salgado de São Félix; B) amostra de granada mais preservada proveniente de Queimadas. Símbolos: $\downarrow$ (FeO); $\mathbf{\Delta}(\mathrm{MgO}) ; \mathbf{X}$ $(\mathrm{CaO}) ; \mathbf{\square}(\mathrm{MnO})$.

A granada das rochas metamáficas de Itabaiana também é rica na molécula de almandina (Fig. 5), mostrando um ligeiro decréscimo desse componente da granada das associações granulíticas para a granada metaestável preservada nos anfibolitos (64,9 - 60,2). Esta granada apresenta também zoneamento com ligeiro enriquecimento em Fe e Mn e empobrecimento em Ca e Mg do núcleo para as bordas (Fig. 7).

Piroxênio De acordo com a classificação de Morimoto (1968), os clinopiroxênios das ocorrências de Quei- madas, Itatuba e Salgado de São Félix são cálcicos e mostram composição variando de $\mathrm{Wo}_{25} \mathrm{En}_{40} \mathrm{Fs}_{35}$ a Wo${ }_{50} \mathrm{En}_{10} \mathrm{Fs}_{40}$ (Fig. 8a). Os clinopiroxênios são levemente zonados e, ainda que não apresentem um comportamento sistemático, verifica-se um enriquecimento em $\mathrm{Fe}$ e $\mathrm{Mg}$ e diminuição em $\mathrm{Ca}$ do núcleo para as bordas. Esse comportamento é mais fortemente evidenciado em clinopiroxênios que possuem os bordos substituídos por ortopiroxênio (Fig. 9). Nestes ortopiroxênios os teores de Fe e Mg são marcadamente mais elevados, sugerindo que a transição da facies granulito de alta 


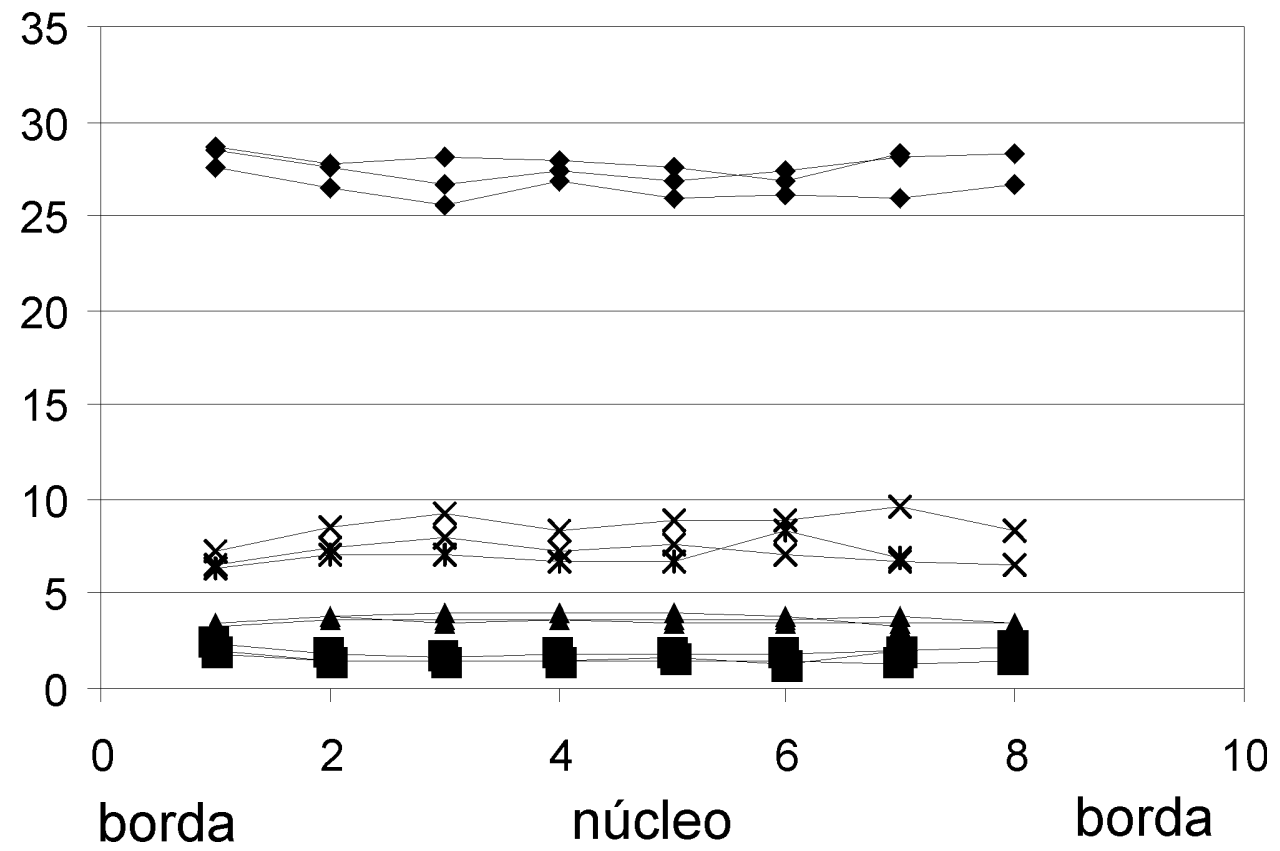

Figura 7 - Perfil analítico para porfiroblastos de granada provenientes de amostras de granada-piroxenitos de Itabaiana. Símbolos: $(\mathrm{FeO})$; $(\mathrm{MgO}) ; \times \mathbf{X} \mathrm{CaO}) ; \mathbf{\square}(\mathrm{MnO})$.

Wo

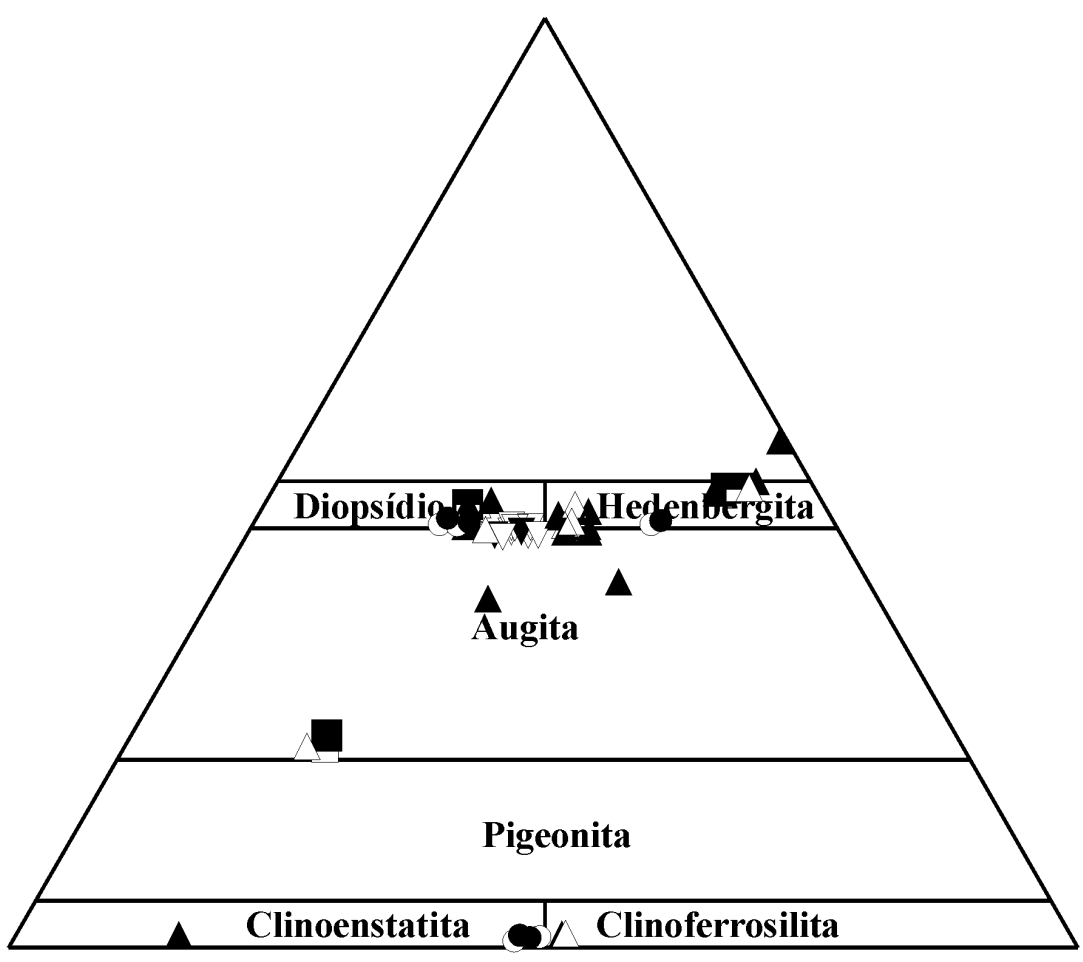

\section{En}

Figura 8 - Diagrama En x Wo x Fs (Morimoto, 1968) mostrando a classificação de clinopiroxênios para as rochas estudadas. Símbolos: Itatuba - $\boldsymbol{\Delta}$ (clinopiroxênio-núcleo; $\triangle \quad$ clinopiroxênio-borda); $\square$ (clinopiroxênios envoltos por simplectitas); Queimadas - ( $\mathbf{X}$ clinopiroxênio-núcleo; + clinopiroxênio-borda); Itabaiana- ( $\boldsymbol{\nabla}$ clinopiroxênio-núcleo). 
pressão para a facies granulito de baixa pressão ocorreu por descompressão, sendo marcada pelo consumo de Fe e Mg e liberação de Ca, o qual foi incorporado nas assembléias simplectíticas. Anfibolitização provoca um decréscimo em Fe nos bordos de ortopiroxênio, o qual é transferido para os anfibólios cedo-formados.

Clinopiroxênio rico em onfacita, típico da facies eclogito, não foi observado. Esta ausência pode ser explicada pelas texturas de desestabilização e substituição observadas, as quais indicam que a composição original não foi preservada durante os eventos de retrometamorfismo. A presença de clinopiroxênios cálcicos típicos de metamorfismo de condições mais moderadas (granulito e anfibolito), associados às feições de desequilíbrio anteriormente descritas, sugerem retrometarmofismo a partir do facies eclogito.

Nas metamáficas de Itabaiana, o clinopiroxênio é do tipo diopsídio e não apresenta zoneamento sistemático (Fig. 8).

Plagioclásio Os plagioclásios dos retroeclogitos tendem a ser enriquecidos em anortita, entretanto, as composições variam com o tipo textural (Fig. 10). Os plagioclásios que ocorrem associados a anfibólio ou ortopiroxênio, formando simplectitas em volta de clinopiroxênio e granada, e aqueles que ocorrem associados a anfibólio, formando coroas em torno desse mineral, são extremamente enriquecidos em $\mathrm{Ca}$, variando de bytownita a anortita $\left(\mathrm{An}_{80-89}\right)$. Intercrescimentos simplectíticos de ortopiroxênio e plagioclásio rico em Ca são feições comuns de retroeclogitos, interpretadas como o resultado de desestabilização de clinopiroxênios onfacíticos
(Winkstron, 1970; Baker, 1986), promovendo transferência de Ca para o plagioclásio associado (Yang, 2004). Plagioclásio associado a clinopiroxênio e granada, caracterizando assembléias granulíticas, e plagioclásio neocristalizado em equilíbrio com anfibólio apresentam composições similares, variando de andesina a labradorita $\left(\mathrm{An}_{40-67}\right)$, indicando que o aumento em $\mathrm{Na}$ foi decorrente da desestabilização de clinopiroxênio rico em onfacita durante descompressão.

Nas rochas de Itabiana, o plagioclásio possui composição labradorítica $\left(\mathrm{An}_{50-70}\right)$, compatível com sua formação em temperaturas elevadas, em condições de facies granulito (Fig. 10).

Anfibólio Os anfibólios das rochas estudadas são essencialmente cálcicos (Leake et al., 1997), observandose, entretanto, ampla variação composicional segundo as características texturais (Fig. 11).

Nos retroeclogitos, os anfibólios dos intercrescimentos simplectíticos em volta das granadas e os pseudomorfos de clinopiroxênio são Fe-edenitas e Fehornblendas com valores de $\mathrm{Mg} \#\left[\mathrm{Mg} /\left(\mathrm{Mg}+\mathrm{Fe}^{2+}\right)\right]$ variando entre 0,45 e 0,49 . Aqueles que formam coroas em volta das granadas são marcados por um decréscimo nos valores de $\mathrm{Mg \#}(0,35-0,29)$, projetando-se no campo das tshermakitas. Anfibólios com essas composições são formados em retroeclogitos quando ocorre diminuição de temperatura e pressão, marcando a transição da facies eclogito para condições metamórficas mais moderadas (Ungaretti et al., 1983; Messiga et al., 1991). Estes são amplamente citados na literatura como típicos de anfibolitos formados a partir da retrogressão de eclo-

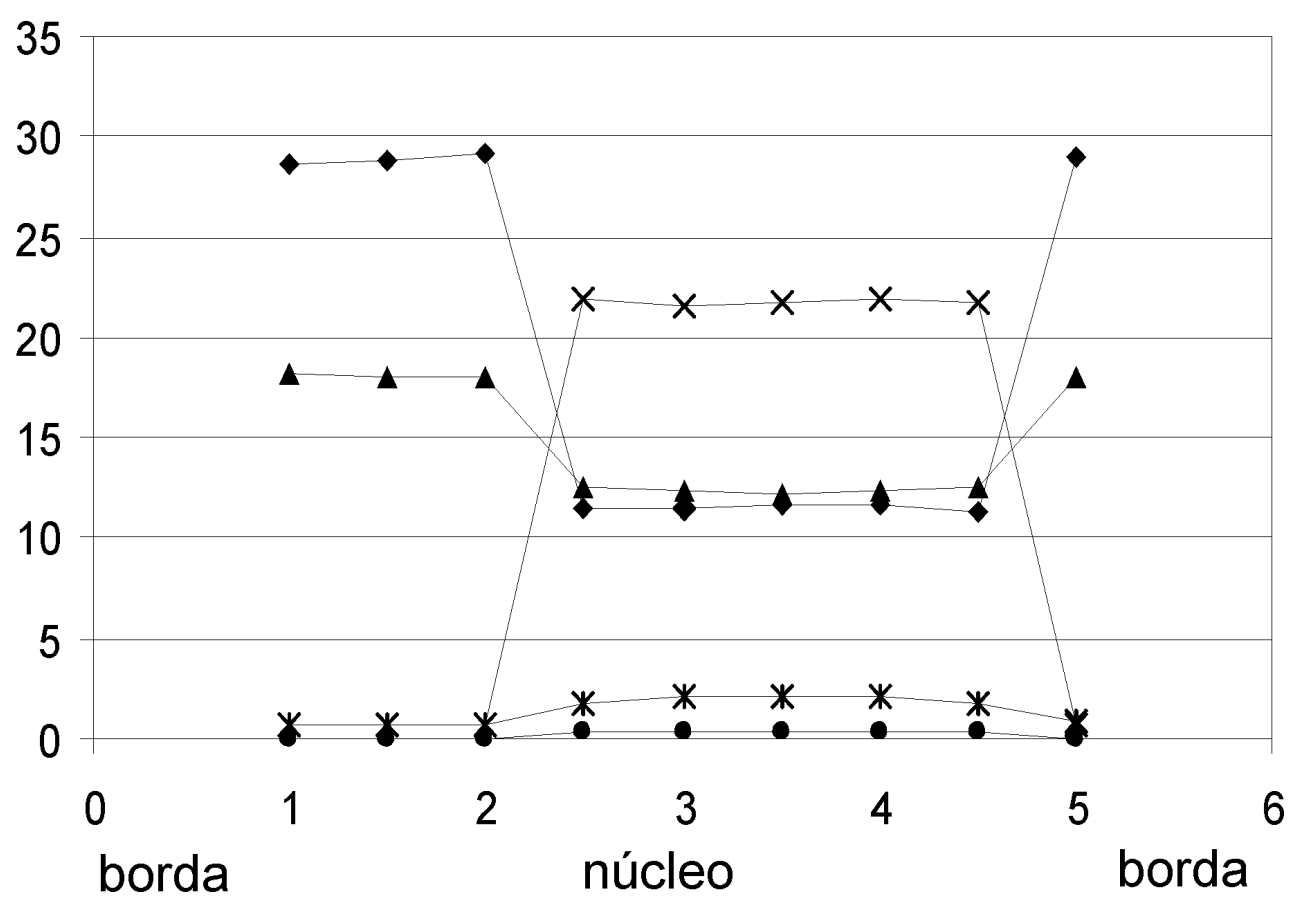

Figura 9 - Perfil analitico para clinopiroxênios envoltos por coroas de ortopiroxênio provenientes de amostras de granada-piroxenitos de Queimadas. Simbolos: $(\mathrm{FeO}) ; \boldsymbol{\Delta}(\mathrm{MgO}) ; \mathbf{X}(\mathrm{CaO})$;

$\left(\mathrm{Na}_{2} \mathrm{O}\right) *\left(\mathrm{Al}_{2} \mathrm{O}_{3}\right)$. 


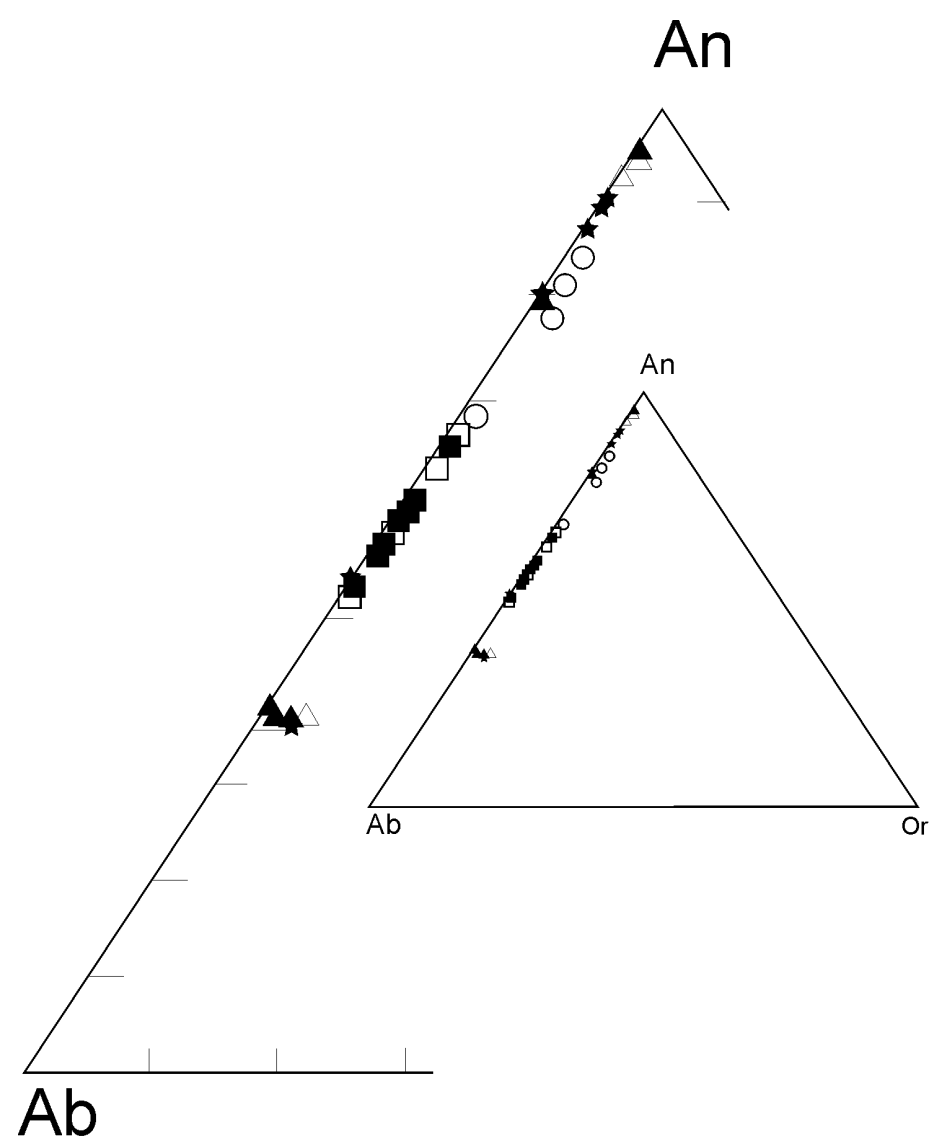

Figura 10 - Diagrama Ab-Or-An (Deer et al., 1962) mostrando a variação composicional dos plagioclásios das rochas metamáficas estudadas. Símbolos: Itabaiana - (assembléias granulíticas - núcleo); (assembléias granulíticas - borda); Itatuba * (coroas de anfibólio + plagioclásio); $\boldsymbol{\Delta}$ (assembléias granulíticas - núcleo); $\triangle$ (assembléias granulíticas - bordo); *-simplectitas); Queimadas - • (assembléias granulíticas - núcleo); O (assembléias granuliticas - bordo).

gitos (Brueckner et al., 1997; Engvik \& Andersen, 2000; Wain et al. 2001; Molina et al., 2002; entre outros). Os anfibólios que ocorrem em equilíbrio com plagioclásio, formados às expensas das simplectitas, apresentam uma maior variação composicional, distinguindo-se um grupo com valores de $\mathrm{Mg \#}$ elevados $(0,49-0,68)$, classificados como Mg-hornblendas e Mg-hastingsitas, similares aos anfibólios observados nos anfibolitos bandados que marcam o reequilíbrio na facies anfibolito. Anfibólios com essas características são interpretados como resultantes da total desestabilização de onfacitas, gerando anfibolitos formados em condições de baixas temperatura e pressão (Messiga et al., 1991). Um segundo grupo de anfibólios neocristalizados (Fe-tschermakitas, Fe-pargasitas e Fe-hornblendas) apresenta baixos valores de $\mathrm{Mg} \#$ $(0,30-0,42)$. Composições similares são observadas nas rochas de Itabaiana, que apresentam valores de $\mathrm{Mg} \#$ $(0,32-0,59)$, classificando-se como tshermakitas, Fetshermakitas e Fe-pargasitas (Fig. 11), típicas da transição entre as facies granulito e anfibolito (Cox \& Indares,
1999).

GEOBAROMETRIA E GEOTERMOMETRIA A determinação das condições P-T para as rochas de Itatuba e Salgado de São Félix foi feita mediante a aplicação simultânea do geotermômetro granada-clinopiroxênio (Ellis \& Green, 1979) e o geobarômetro granadaclinopiroxênio-plagioclásio (Newton \& Perkins, 1982). A estimativa das condições metamórficas reinantes durante a fase eclogítica não foi estabelecida devido à ausência de onfacitas preservadas. Para as associações envolvendo granada-clinopiroxênio com textura granoblástica, a temperatura varia de $657,9^{\circ} \mathrm{C}$ a $729,0^{\circ} \mathrm{C}$, com pressões variando no intervalo 5,6-6,5 kb, quando se considera as composições de núcleo dos minerais empregados nas referidas calibrações. Para as bordas dos minerais, as pressões obtidas variam de 5,3 a 6,1 kb e as temperaturas, entre $754.9^{\circ} \mathrm{C}$ e $783.0^{\circ} \mathrm{C}$. Quando se utiliza a composição de granadas envoltas por simplectitas verifica-se que a pressão é constante, atingindo 


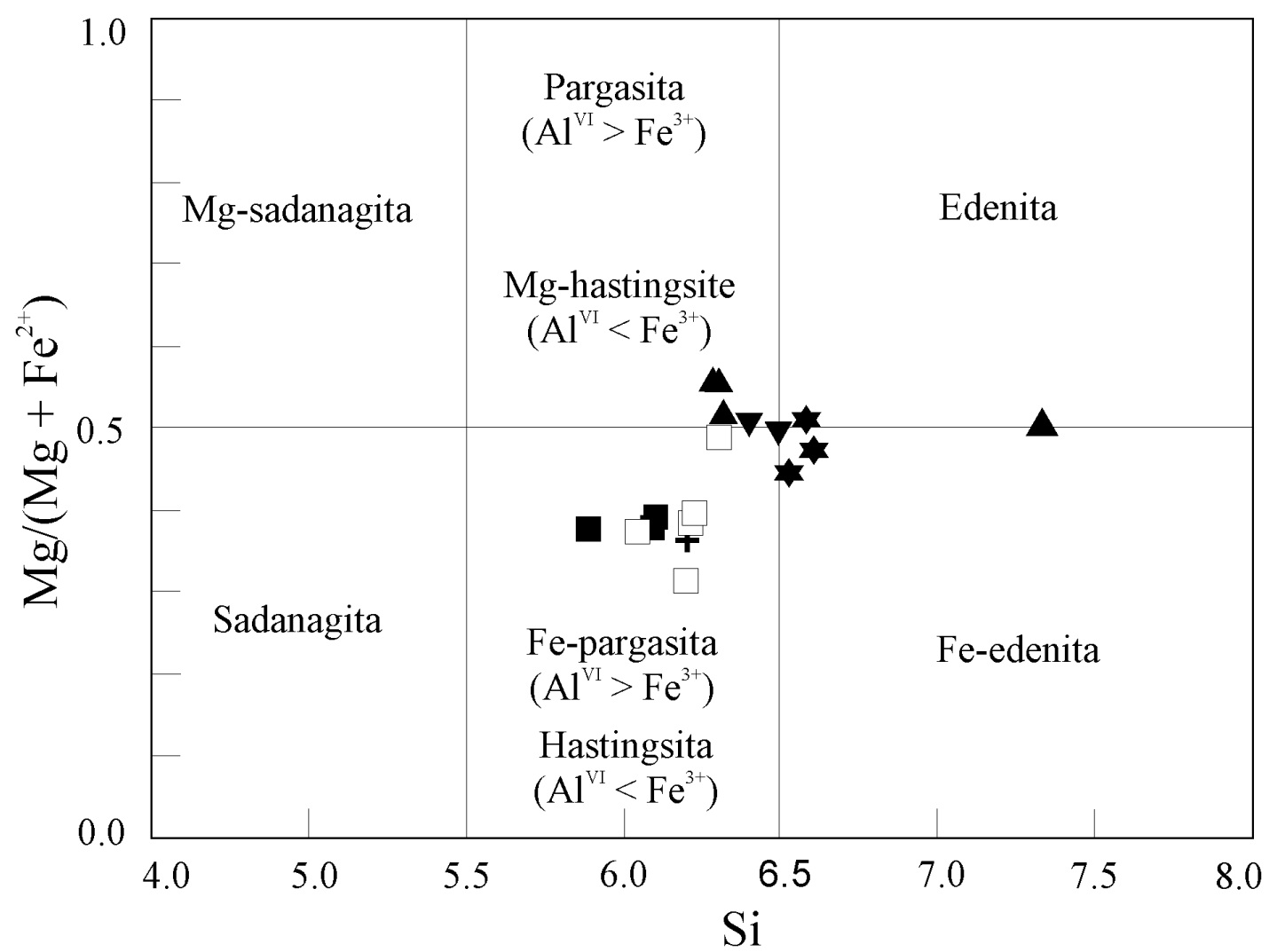

Figura 11 - Diagrama de Leake et. al. (1997) mostrando a classificação dos anfibólios das rochas estudadas. Símbolos: Itatuba: anfibólios neoformados - $\boldsymbol{\Lambda}$ (núcleo), anfibólios neoformados - $\nabla$ (borda); $*$ (simplectitas); $\boldsymbol{\nabla}$ (peseudomorfos); Queimadas: coroas de clinopiroxênio - $\downarrow$ (núcleo), coroas de clinopiroxênio - $\diamond$ (borda); neocristalizados $\bullet$ (núcleo); O (borda); Itabaiana: neocristalizados + pseudomorfos $\square$ (núcleo), $\square$ (borda).

$5,5 \mathrm{~kb}$, enquanto que a temperatura varia entre $720,5^{\circ} \mathrm{e}$ $772,5^{\circ} \mathrm{C}$ para as composições de borda e entre $742,9^{\circ} \mathrm{e}$ $761,9^{\circ} \mathrm{C}$ para as composições de núcleo. Excepcionalmente, valores mais elevados foram registrados quando se utilizou granadas que se apresentam enriquecidas em $\mathrm{Ca}$, com temperaturas variando entre $1033,8^{\circ} \mathrm{C}$ e $1170.0^{\circ} \mathrm{C}$ e pressões variando de $6,7 \mathrm{~kb}$ a $7,2 \mathrm{~kb}$ para as composições de borda e núcleo, respectivamente.

Nos dois tipos texturais considerados para as estimativas das condições P-T, embora se observe uma tendência de valores mais baixos nos bordos, indicando sobrecrescimento nas novas condições em minerais formados em condições metamórficas mais elevadas, em algumas amostras observou-se o inverso, indicando que as reações metamórficas não se processaram de forma homogênea, ficando preservadas porções onde essas reações cessaram antes de atingir sua total complementação.

A aplicação simultânea do geotermômetro granada-clinopiroxênio (Ellis \& Green, 1975) e do geobarômetro granada-plagioclásio-clinopirpoxênio (Newton \& Perkins, 1983) para as rochas de Itabaiana indicaram dois intervalos de P-T: um mais elevado, com temperaturas variando de $859,2^{\circ} \mathrm{C}$ a $829,7^{\circ} \mathrm{C}$ e pressão de $6.7 \mathrm{~kb}$ e $6.4 \mathrm{~kb}$, considerando composições de núcleo e bordo de granadas em equilíbrio na associação granulítica, e um outro mais baixo, com tempe- ratura estimada de $659,7^{\circ} \mathrm{C}$ e pressão de $2,9 \mathrm{~kb}$, quando consideradas as composições de borda das granadas metaestáveis na facies anfibolito.

CONCLUSÕES As análises petrográficas/texturais e as relações de campo sugerem que as rochas metamáficas das áreas de Queimadas, Itatuba e Salgado de São Félix (PB), associadas às ocorrências de $\mathrm{Fe}-\mathrm{Ti}$, foram submetidas a metamorfismo de alto grau, sugerindo uma seqüência de quatro facies metamórficas, evoluindo a partir de uma suposta facies eclogito, passando, sucessivamente, para condições das facies granulito, anfibolito e, por último, facies xisto verde.

Ainda que os dados de química mineral tenham revelado apenas uma amostra com granada de composição característica de eclogitos e não tenham indicado a presença de onfacita, as relações texturais indicam substituição desses minerais sob condições de alta temperatura, o que, provavelmente, dificultou a detecção de remanescentes da fase eclogítica. As análises químicas revelaram a presença de granada rica em $\mathrm{Ca}$ e $\mathrm{Mg}$ que poderia representar relictos eclogíticos metaestáveis. As composições químicas dos anfibólios são mais um indício para se validar uma evolução a partir de fases formadas em condições de temperatura e pressão elevada. Anfibólio rico na molécula de Fe-edenita, associados 
às coroas que envolvendo granada, e anfibólio tschermakítico nos intercrescimentos simplectíticos em volta de clinopiroxênio sugerem decréscimo de temperatura a partir do estágio eclogítico. Anfibólio de composição edenítica e Mg-hornblenda, neocristalizados, associados a plagioclásio e formados a partir das simplectitas, indicam decréscimo de temperatura e pressão, favorecendo reequilíbrio na facies anfibolito baixo, marcando a total desestabilização de clinopiroxênio onfacítico.

A anfibolitização dessas rochas está provavelmente relacionada a processos de exumação da crosta, a exemplos de exposições superficiais de retroeclogitos em outras regiões da terra. Zonas de cisalhamentos extensionais e/ ou diferença de densidade (Ernst et al. 1997) podem explicar a exumação de assembléias de alto grau. A Zona de Cisalhamento de Campina Grande, de direção E-W a NESW, que se estende ao longo desse alinhamento de máficas, desde Queimadas até Itabaiana, já apresenta indícios de tectônica transicional entre estágios dúctil e rúptil são associadas a magmatismo granítico tipo-A, a exemplo do Granito de Queimadas (Almeida et al. 2003).

Rochas metamórficas de alta pressão como eclogitos geralmente evidenciam processos de subducção relacionados a limites de placas convergentes. A identificação de retreclogitos em Floresta-PE (Beurlen, 1988), Custódia-PE (Melo, 1998), Itatuba, Queimadas e Salgado de São Félix (PB), associada à presença de anomalias gravimétricas positiva-negativas, sugerem a presença de uma zona de sutura continental de direção geral NE-SW a E-W no domínio Paleoproterozóico da Faixa Pajeú-Paraíba. A caracterização de uma seqüência magmática de margem continental na área de Floresta-PE por (Santos, 1995) corrobora esta hipótese. As rochas metamáficas de Itabaiana não apresentam indícios de metamorfismo na facies eclogito, tendo sido registradas assembléias em facies granulito e anfibolito, não sendo, assim, possível associá-las aos mesmos eventos metamórficos que atingiram as assembléias anteriormente descritas.

Agradecimentos Os autores agradecem ao CNPq pelo apoio financeiro que tornou possível a realização desse trabalho. O primeiro autor também agradece a concessão de Bolsa DCR, contemplada junto à Universidade Federal da Paraíba durante o desenvolvimento do projeto Petrogênese de Rochas Metamáficas do Terreno Pajeú-Paraíba: Área Limoeiro (PE) - Itatuba (PE) Itabaiana (PB) processo 301040/99-0 (NV). Deixamos também nossos agradecimentos ao revisor, pela análise detalhada, que contribuiu valiosamente para a qualidade do texto ora apresentado.

\section{Referências}

Almeida F.F.M., Hasui Y., Brito Neves B.B., Fuck R.A. 1977. Províncias estruturais brasileiras. In: SBG, Simp. Geol. NE, 8, Atas, p. 363-391.

Almeida C.N., Beurlen H., Guimarães I.P., Sampaio A.S.S. 1997. High pressure metamorphised Fe-Ti ore hosting island-arc tholeiites ai Itatuba (Paraíba) as na indication of a proterozoic suture in the Pajeú-Paraíba fold belt, Borborema Province, Northeastern Brasil. Intern. Geol. Rev., 30:578-588.

Baker A.J. 1986. Eclogitic amphibolites from the Garimpian Moines. Mineral Mag., 50:217-221.

Beurlen H. 1988. Fazenda Esperança (Bodocó) e Riacho da Posse (Floresta): duas ocorrências atípicas de Fe-Ti no Estado de Pernambuco. Tese para concurso de professor titular, UFPE, Recife, 72p.

Beurlen H., Silva Filho A.F., Guimarães I.P., Brito S.A. 1992. Proterozoic C-type eclogites hosting unsual Ti-Fe $\pm \mathrm{Cr}$ $\pm \mathrm{Cu}$ mineralization in Northeastern Brazil. Precambrian Res., 58:195-214

Bittar S.M.B. 1998. Faixa Piancó-Alto Brígida: Terrenos tectono-estratigráficos sob regimes metamórficos contrastantes. Tese de Doutorado, Instituto de Geociências, Universidade de São Paulo. 126p.

Brito Neves B.B. 1983. O mapa geológico do Nordeste Oriental do Brasil, escala 1:1.000.000. Tese de Livre Docência, Instituto de Geociências/Universidade de São Paulo, 171p.

Brito Neves B.B., Sato K. 2001. Marcos cronogeológicos da evolução do embasamento pré-Ordoviciano da Plataforma Sul-Americana-avaliação para o final do ano
2000. Estudos Geológicos-Série B Estudos e Pesquisas, Recife-UFPE, 11:01-25.

Brito Neves B.B., Van Schmus W.R., Hackspacher P.C., Santos E.J. 1995a. Geocronologia da Borborema, 1995: os fatos e as questões abertas. In: SBG, Simp. Geol. NE, 16, Boletim, 2:363-391.

Brito Neves B.B., Van Schmus W.R., Santos E.J., Campos Neto M.C., Kozuch M. 1995b. O Evento Cariris Velhos na Província Borborema: integração de dados, implicações e perspectivas. Rev. Bras. Geoc., 25(4):279296.

Brito Neves B.B., Santos E.J., Van Schmus W.R. 2000. The tectonic history of the Borborema Province. In: Cordani U.G., Milani E.J., Thomaz Filho A., Campos D.A. (eds.) Tectonic Evolution of the South American Continent. Intern. Geol. Cong., 38, p.151-182.

Brito Neves B.B., Campos Neto M.C., Van Schmus W.R., Santos J.E. 2001. O "Sistema Pajeú-Paraíba" e o "Maciço" São José do Campestre no leste da Borborema. Rev. Bras. Geoc., 31(2):173-184.

Brito Neves B.B., Campos Neto M.C., Van Schmus W.R., Fernandes T.M.G., Souza S.L. 2001. O Terreno Alto Moxotó no leste da Paraíba ("Maciço Caldas Brandão"). Rev. Bras. Geoc., 31(2):185-194.

Brueckner H., Gilotti J.A., Nutman Allen P. 1998. Caledonian eclogite-facies metamorphism of Early Proterozoic protoliths from the north-east Greenland Eclogite Province. Contrib. Mineral. Petrol., 130:103-120.

Costa A.C., Mendes V.A., Rocha D.E.G.A., Andrade D.A. 1980. Projeto Extremo Nordeste do Brasil. Relatório 
Final, Recife, DNPM/CPRM, Vol. I e II, 337p.

Cox R.A. \& Indares A. 1999. Transformation of Fe-Ti gabro to coronite, eclogite and amphibolite in the Baie du Nord segment, Manicouagan Imbricate Zone, eastern Greville Province. J. Metamorphic Geol., 17:537-555.

Deer W.A., Howie R.A., Zusmann J. 1962. Rock forming minerals. London, Longmans, p. 379.

Ellis D.J. \& Green D.H. 1979. An experimental study of the effect of Ca upon garnet-clinopyroxene $\mathrm{Fe}-\mathrm{Mg}$ exchange equilibria. Contrib. Mineral. Petrol., 71:13-22.

Engvik A.K. \& Andersen T.B. 2000. Evolution of Caledonian deformation fabrics under eclogite and amphibolite facies at Vardalsneset, Western Gneiss Region, Norway. J. Metamorphic Geol, 18:241-257.

Ernst W.G., Maruyama S., Wallis S. 1997. Buoyancy-driven, rapid exhumation of ultrahigh pressure metamorphosed continental crust. In: National Academy of Sciences of the United States of America, Proceedings, 94:95329537.

Guimaraes I.P. \& Brito Neves B.B. 2005. Geoquímica e significado do plutonismo Eo-Neoproterozóico no limite norte do domínio estrutural central da Província Borborema. In: SBG, Simp. Geol. NE, 21, Boletim, 1:6871.

Leake B.E., Woolley A.R., Arps C.E.S., Birch W.D., Gilbert M.C., Grice J.D., Hawthorne F.C., Kato A., Kisch H.J., Krivovichev V.G., Linthout K., Laird J., Mandarino J.A., Maresch W.V., Nickel E.H., Rock N.M.S., Schumacher J.C., Smith D.C., Stephenson C.N., Ungaretti L., Whitaker J.W., Youzhi, G. 1997. Nomenclature of amphiboles: Report of the Subcommittee on Amphiboles of the International Mineralogical Association, Commission on New Minerals and Mineral Names. Am. Mineral., 82:1019-1037.

Mariano G., Neves S.P., Da Silva Filho A.F. 1999. Dioritos da associação potássica cálcio-alcalina, Província Borborema, NE do Brasil: geoquímica do manto litosférico e implicações para o conceito de terrenos. In: SBGq, Cong. Geoq. dos Países de Língua Portuguesa, 5, Cong. Bras. Geoq., 7, Porto Seguro, Anais, p. 543-545.

Medeiros V.C. \& Torres H.H.F. 1999. PLGB-CPRM. Folha Sumé (SB 24-Z-D-V), Estados da Paraíba e Pernambuco. Escala 1:100.000. Brasília CPRM, 88p.

Melo O.O. 1998. Petrologia e geoquímica das rochas gabroanortositicas e mineralizações de Fe e Ti associadas de Barro Vermelho-Custódia-PE, NE do Brasil. Recife. Tese de Doutoramento, Pós-Graduação em Geociências, Universidade Federal de Pernambuco, 216p.

Messiga B., Tribuzio R. \& Vanucci R. 1991. Mafic and ultramafic pods with eclogitic relicts from the Proterozoic Nagssugtoqidian mobile belt of east Greenland. Lithos, 25:101-118

Molina J.F., Austrheim H., Glodny J., Rusin A. 2002. The eclogites of the Mrun-Keu complex. Polar Urals (Russia): fluid control on reaction kinetics and metasomatism during high $\mathrm{P}$ metamorphism. Lithos, 61:55-78.

Morimoto N. 1988. Nomenclature of pyroxenes. Bull. Mineral, 111:535-550.

Mysen B. 1972. Five clinopyroxenes in the Hareidlande eclogites. Cont. Mineral. Petrol., 34:315-325.
Neves S.P., Mariano G., Guimarães I.P., da Silva Filho A.F. 2000. Geoquímica do manto litosférico e acresção de terrenos tectônicos na Província Borborema. In: SBG, Simp. Geol. NE, 16, Boletim, p. 99.

Newton R.C \& Perkins D.III. 1982. Thermodinamic calibration of geobarometers based on the assemblages garnet - plagioclase - orthopyroxene (clinopyroxene)quartz. Am. Mineral., 67:203-222.

Oliveira R.G. \& Santos E.J. 1993. Seção geológica-geofísica e inferências geotectônicas na porção centro-sul da Província Borborema. In: SBGf, Cong. Intern. SBGf., 3, Resumos, 1:643-747.

Rand H., Manso V.A.V., Sial A.N., Brito Neves B.B. 1980. Gravimetric and magnetometric study of the Late Precambrian folding system; NE-Brasil. In: SBG, Cong. Bras. Geol., Boletim, 5:2700-2708.

Santos E.J. 1995. O complexo granítico Lagoa das Pedras: acresção e colisão na região de Floresta (Pernambuco), Província Borborema. Tese de Doutoramento, Instituto de Geociências, Universidade de São Paulo, 219p.

Santos E.J. \& Medeiros V.C. 1997. Constraints from granitic plutonism on proterozoic crustal growth of the Zona Transversal Domain, Borborema Province, NE Brazil. In: ISGAM, 2, Extended Abstracts, p.237-239.

Santos J.E. \& Medeiros V.C. 1999. Constraints from granitic plutonism on Proterozoic crustal growth of the Transverse Zone, Borborema Province, NE Brazil. Rev. Bras. Geoc., 29:73-84.

Simpson C. 1985. Deformation of granitic rocks across the brittle ductile transition. J. Struct. Geol.,7(5):503-511.

Ungaretti L., Lombardo B., Domeneghetti C., Rossi G. 1983. Crystal-chemical evolution of amphiboles from eclogitized rocks of the Sesia-Lanzo zone, Italian western Alps. Bulletin Mineralogie, 106:645-672.

Van Schmus W.R., Brito Neves B.B., Hackspacher P.C., Babinski M. 1995. U/Pb and $\mathrm{Sm} / \mathrm{Nd}$ geochronologic studies of the Eastern Borborema province, Northeastern Brazil: initial conclusions. Journ. South Am. Earth Sci., 8:267-288

Vauchez A., Neves S.P., Caby R., Corsini M., Egydio-Silva M., Arthaud M., Amaro V. 1995. The Borborema Shear Zone. J. South Am. Earth Sci., 8:247-266.

Vernon R.H. 1991. Questions about mymerkite in deformed rocks. J. Struct. Geol., 13:979-985.

Wain A.L., Waters D.J., Austrheim H. 2001. Metaestability of granulites and processes of eclogitization in the UHP region of westeern Norway. J. Metamoorphic. Geol., 19:609-625.

Wikstrom A. 1970. Electron microprobe studies of the alteration of omphacite in eclogites from Nordfjord area, Norway. Norsk. Geol. Tidssk., 50:137-155.

Yang T.N. 2004. Retrogreded textures and associated mass transfer: evidence for aqueous fluid action during exhumation of the Qinglongshan eclogite, Southern Sulu ultrahigh-pressure metamorphic terrane, eastern China. J. Metamorphic Geol., 22:653-669.

Manuscrito ID 14013

Submetido em 27 de abril de 2009 Aceito em 14 de agosto de 2009 